DEPARTMENT OF THE INTERIOR

UNITED STATES GEOLOGICAL SURVEY

\title{
LANDFORMS IN THE BOULDER-FORT COLLINS-GREELEY AREA, FRONT RANGE URBAN CORRIDOR, COLORADO
}

By Eleanor J. Crosby 